\title{
REKOMENDASI FITUR YANG MEMPENGARUHI HARGA SEWA MENGGUNAKAN PENDEKATAN MACHINE LEARNING
}

\author{
Bambang Wisnuadhi ${ }^{1}$, Irwan Setiawan ${ }^{* 2}$ \\ 1,2 Jurusan Teknik Komputer dan Informatika - Politeknik Negeri Bandung \\ Email: ${ }^{1}$ bwisnu@jtk.polban.ac.id, ${ }^{2}$ irwan@jtk.polban.ac.id \\ *Penulis Korespondensi
}

(Naskah masuk: 24 Februari 2020, diterima untuk diterbitkan: 19 Juli 2021)

\begin{abstract}
Abstrak
Perkembangan Teknologi Infromasi, internet, dan perangkat bergerak telah mengubah perilaku konsumen dalam menjalankan aktivitasnya. Hal ini direspon oleh industri dengan menyediakan berbagai aplikasi berbasis web dan perangkat bergerak dalam interaksinya dengan pelanggan. Salah satu industri yang beradaptasi dengan perubahan teknologi dan perilaku konsumen ini adalah industri pariwisata dan perhotelan. Kebutuhan konsumen yang sebelumnya menggunakan akomodasi wisata tradisional seperti hotel, berubah menjadi lebih memilih rumahrumah penduduk disekitar tempat wisata sebagai tempat penginapan sementara wisatawan. Perubahan ini berdampak kepada semakin banyaknya properti pribadi yang disewakan sehingga menyebabkan persaingan harga sewa. Harga sewa merupakan salah satu faktor penting yang dipertimbangkan calon penyewa dalam menentukan properti yang akan disewanya. Hal ini tentunya membuat para pemiliki properti harus memikirkan strategi penentuan harga sewa agar propertinya laku dipasaran. Penelitian ini bertujuan untuk mendapatkan fitur apa saja yang dapat mempengaruhi penentuan harga sewa properti berdasarkan data pengguna Airbnb di Berlin. Data penelitian diambil dari dataset yang disediakan oleh InsideAirbnb berupa file dengan format CSV. Penelitian dilakukan menggunakan teknik machine learning dengan pendekatan algoritma XGBoost. Terdapat lima tahapan pengerjaan dalam penelitian ini, yaitu data understanding, data pre-processing, exploratory data analysis, pemodelan, dan insights. Hasil yang didapatkan dari penelitian ini adalah room type private room, room type entire homelapt, dan cancellation policy super strict 60 days merupakan tiga fitur tertinggi yang mempengaruhi penentuan harga sewa. Luas properti menempati urutan keempat berdasarkan rekomendasi algoritma yang diterapkan.
\end{abstract}

Kata kunci: harga sewa, fitur harga, XGBoost, machine learning

\section{FEATURES IMPORTANT THAT AFFECT RENTAL PRICES USING MACHINE LEARNING APPROACHES}

\begin{abstract}
The development of information technology, the internet, and mobile devices has changed the behavior of consumers in carrying out their activities. The industry responded by providing various web-based and mobile applications in their interactions with customers. The tourism and hospitality industry is adapting to changes in technology and consumer behavior. The needs of consumers who previously used traditional tourist accommodations such as hotels have changed to prefer residents' houses around tourist attractions as their temporary lodging. This change has an impact on the increasing number of private properties being leased, causing competition in rental prices. It is undeniable that the rental price is one of the essential factors that prospective tenants consider in making choices. This certainly makes property owners, who will rent out their properties, have to think about rental pricing strategies. This study aims to obtain any features that affect pricing based on Airbnb user data in Berlin. The study was conducted using machine learning techniques with the XGBoost algorithm approach. There are five stages of work in this study, namely understanding data, preprocessing data, exploratory data analysis, modeling, and insights. The results obtained from this study are room type private room, room type entire home / apt, and cancellation policy type super strict 60 are the three highest features that affect price determination. Property size ranks fourth based on algorithmic recommendations.

Keywords: rent pricing, feature importance, XGBoost, machine learning
\end{abstract}

\section{PENDAHULUAN}

Perkembangan internet dan teknologi perangkat bergerak yang semakin pesat secara tidak langsung berdampak terhadap berbagai model bisnis dan perilaku konsumennya. Industri pariwisata dan perhotelan merupakan salah satu industri yang terkena pengaruhnya (Farisha Isa et al. 2017). Banyak wisatawan yang lebih memilih tinggal di kediaman 
orang asing dibandingkan menginap di akomodasi pariwisata tradisional seperti hotel (Guttentag et al. 2018). Menyikapi hal tersebut, banyak bisnis baru yang memanfaatkan teknologi informasi dan perangkat bergerak bermunculan, salah satunya adalaah Airbnb.

Airbnb memulai bisnisnya pada tahun 2008 sebagai suatu model bisnis yang menggabungkan keuntungan wisatawan dengan penduduk di wilayah wisata (Oskam and Boswijk 2016). Layanan yang diberikan Airbnb telah menarik banyak konsumen di seluruh dunia. Pada tahun 2016 dilaporkan lebih dari 100 juta wisatawan menggunakan layanan Airbnb dan lebih dari dua juta listing di seluruh dunia (Guttentag et al. 2018). Salah satu nilai jual yang ditawarkan oleh Airbnb kepada konsumennya adalah beragam fasilitas yang tersedia di rumah yang disewakan dan suasana penginapan yang bernuansa rumah (Guttentag et al. 2018).

Perkembangan industri perhotelan dan pariwisata ini membawa dampak bagi sosial, salah satunya adalah harga sewa properti (Wang and Nicolau 2017). Tidak dapat dipungkiri bahwa harga sewa merupakan salah satu faktor penting yang dipertimbangkan calon penyewa dalam menentukan pilihan. Hal ini tentunya membuat para pemiliki properti, yang akan menyewakan propertinya, harus memikirkan strategi penentuan harga sewa. Beberapa aspek yang dapat dijadikan pertimbangan penentuan harga adalah tersedianya akses pejalan kaki (Yang et al. 2018), akses transportasi bus (Yang et al. 2019), ukuran properti (Li and Chau 2017), akomodasi (Moreno-Izquierdo et al. 2020), dan lain sebagainya.

Teknik machine learning telah banyak digunakan dalam berbagai penelitian (Varma et al. 2018; Phan 2019; Shahhosseini, Hu, and Pham 2020; Oshodi et al. 2019) untuk membantu berbagai pihak dalam menentukan harga sewa properti. Namun penentuan harga sangat dipengaruhi oleh keberadaan (kota atau negara) properti dan perilaku penyewanya. Sehingga peneltian terkait penentuan harga masih terus berkembang.

Pada penelitian ini dilakukan penggunaan teknik machine learning untuk mendapatkan fiturfitur apa saja yang paling mempengaruhi harga sewa berdasarkan data pengguna Airbnb di kota Berlin menggunakan algoritma XGBoost.

\section{METODE PENELITIAN}

Penelitian ini menggunakan pendekatan machine learning untuk mengetahui fitur-fitur apa saja yang paling mempengaruhi host dalam menentukan harga sewa di Airbnb menggunakan algoritma XGBoost. Metode penelitian ditunjukkan pada Gambar 1, terbagi kedalam lima tahapan, yaitu:

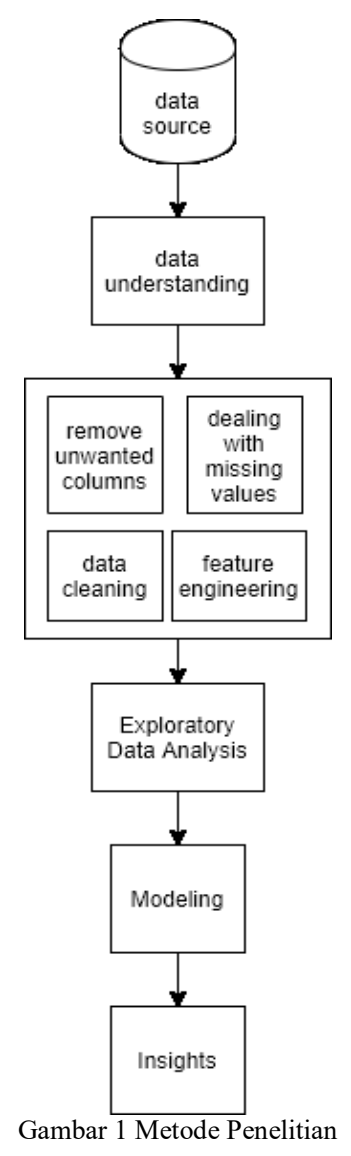

1. Data understanding. Input pada tahapan ini adalah sumber data yang akan dianalisa. Data tersebut kemudian dimasukan kedalam repository lalu dipahami struktur, tipe, isi data, dan kebergunaan data terhadap tujuan penelitian. Luaran dari tahapan ini adalah pemahaman peneliti terhadap data yang akan digunakan dan dataset awal.

2. Data pre-processing. Pemahaman peneliti terhadap data dan dataset hasil dari tahapan sebelumnya merupakan bahan olahan untuk tahapan data pre-processing. Tujuan dari tahapan ini adalah untuk mengurangi kompleksitas data yang berasal dari dunia nyata sehingga dapat lebih mudah diolah (Ramírez-Gallego et al. 2017). Pada tahapan ini dilakukan penghapusan kolom-kolom yang tidak dibutuhkan untuk penelitian, pembersihan data, penanganan nilai NULL, dan feature selection (García, Luengo, and Herrera 2016).

3. Exploratory data analysis (EDA). Dataset hasil pre-processing selanjutnya dianalisa lebih mendalam untuk mengetahui karakteristik utama dari data dengan menggunakan pendekatan visual (Nuzzo 2019; Zgraggen et al. 2017; Batch and Elmqvist 2018). EDA merupakan tahapan penting dalam menginvestigasi data dengan tujuan mendapatkan pola-pola data (Jebb, Parrigon, and Woo 2017), menemukan anomali (Camacho, Rodríguez-Gómez, and Saccenti 2017), dan menguji hipotesa (Bondarev 2019). 
4. Pemodelan (Modeling). Penelitian ini menggunakan algoritma XGBoost untuk mendapatkan feature importance dari dataset.

5. Insights. Pada tahap dari dilakukan penarikan kesimpulan berdasarkan temuan-temuan yang didapatkan pada tahapan-tahapan sebelumnya.

\section{HASIL DAN PEMBAHASAN}

Bagian ini membahas hasil-hasil dari tahapan data understanding, data pre-processing, exploratory data analysis, dan modeling.

\subsection{Data Understanding}

Data understanding merupakan tahapan awal dalam penelitian ini. Tujuan akhir dari tahapan ini adalah untuk mendapatkan pemahaman mengenai data dan keadaan data yang akan digunakan dalam penelitian. Data yang digunakan didapatkan dari http://insideairbnb.com/get-the-data.html. Data terdiri dari lima dataset bertipe csv, yaitu calendar_summary, listings, listings_sumarry, neighbourhoods, reviews, dan reviews_summary. Hasil pemahaman awal dari semua dataset ditunjukan pada Tabel 1.

\begin{tabular}{lrr}
\multicolumn{3}{c}{ Tabel 1 Ringkasan dataset } \\
\hline Nama Dataset & $\begin{array}{c}\text { Banyaknya } \\
\text { Baris }\end{array}$ & $\begin{array}{c}\text { Banyaknya } \\
\text { Kolom }\end{array}$ \\
\hline calendar_summary & 8.231 .480 & 4 \\
listings & 22.552 & 16 \\
listings_sumarry & 22.552 & 96 \\
neighborhoods & 139 & 2 \\
reviews & 401.963 & 2 \\
reviews_summary & 401.963 & 6 \\
\hline
\end{tabular}

Pada penelitian ini digunakan data yang berasal dari file listings_summary.csv karena pada file tersebut terdapat data-data yang relevan dengan tujuan penelitian. Tipe data yang ada dalam dataset tersebut terdiri dari data numerical dan categorical. Pada dataset ditemukan ada beberapa kolom yang memiliki nilai $N U L L$. Dari 96 kolom yang ada, tidak semua kolom digunakan dalam penelitian. Data yang akan digunakan dalam penelitian ini berjumlah 23 kolom dengan daftar nama seperti ditunjukkan padaError! Not a valid bookmark self-reference. Pada data yang ada, terdapat tiga tipe kamar yaitu private room sebanyak $51 \%$, entire homelapt sebanyak $48 \%$, dan shared room sebanyak $1 \%$.

\subsection{Data Pre-processing}

Setelah mendapatkan pemahaman terkait data yang akan digunakan, dilakukan kegiatan preprocessing terhadap data. Langkah pertama adalah penghapusan kolom pada dataset. Kolom yang dipertahankan sesuai dengan Tabel 2.
Tabel 2 Daftar nama kolom yang digunakan

\begin{aligned} \hline No & Nama Kolom & No & \multicolumn{1}{c}{ Nama Kolom } \\ \hline 1 & price & 13 & latitude \\ 2 & space & 14 & longitude \\ 3 & description & 15 & cleaning_fee \\ & host_has_profile_ & 16 & security_deposit \\ 4 & pic & 17 & extra_people \\ 5 & property_type & 18 & guest_included \\ 6 & room_type & 19 & minimum_nights \\ 7 & accommodates & 20 & instant_bookable \\ 8 & bathrooms & 21 & is_business_travel_ready \\ 9 & bedrooms & 22 & cancellation_policy \\ 10 & bed_type & 23 & $\begin{array}{l}\text { neighbourhood_group_clea } \\ \text { nsed }\end{array} \\ 11 &$ amenities & & \\ 12 & square_feet & & \end{aligned}

Dari 23 kolom yang ada, terdapat empat kolom yang memiliki nilai bertipe uang, yaitu price, cleaning fee, extra people, dan security deposit. Pada keempat kolom ini dilakukan pembersihan data dikarenakan ditemukan beberapa data yang angkanya tidak logis. Seperti pada kolom price, ada beberapa isian yang bernilai nol atau $€ 9.000$. Kolom price merupakan kolom yang menampung harga sewa properti. Tidak mungkin ada properti yang disewakan dengan harga nol (gratis). Sehingga data yang memiliki price bernilai nol atau NULL dihilangkan dari dataset. Lain halnya untuk cleaning_fee, extra_people, dan security_deposit, tiga kolom ini dimungkinan memiliki harga nol atau NULL. Aturan penghilangan data untuk kolom bertipe harga mengikuti aturan seperti ditunjukkan pada Tabel 3. Pemilihan aturan tersebut diterapkan setelah memperhatikan sebaran data pada setiap kolom. Hasil dari kegiatan ini didapatkan data yang memenuhi persyaratan adalah 20.670 baris (berkurang 1.882 data).

Tabel 3 Aturan pada kolom bertipe harga

\begin{tabular}{|c|c|}
\hline Nama Kolom & Aturan \\
\hline price & $\begin{array}{l}\text { hilangkan semua data yang bernilai } 0 \text { atau } \\
>400\end{array}$ \\
\hline cleaning fee & hilangkan semua data yang bernilai $>100$ \\
\hline security_deposit & hilangkan semua data yang bernilai $>400$ \\
\hline extra_people & hilangkan semua data yang bernilai $>100$ \\
\hline
\end{tabular}

Berkenaan dengan nilai NULL (missing values) pada kolom yang lainnya, terdapat enam kolom yang memiliki nilai NULL seperti ditunjukkan pada Tabel 4. Untuk menangani kolom yang memiliki nilai NULL, penulis memberlakukan empat pendekatan, yaitu penghapusan kolom, penghapusan data (baris), penggantian nilai, dan pembiaran. Penghapusan kolom squareffeet dan space dari dataset dikarenakan kedua kolom ini memiliki data NULL lebih dari $30 \%$. 
676 Jurnal Teknologi Informasi dan Ilmu Komputer (JTIIK), Vol. 8, No. 4, Agustus 2021, hlm. 673-682

\begin{tabular}{lrr} 
Tabel 4 Kolom yang memiliki nilai NULL dan jumlahnya \\
\cline { 2 - 3 } \multicolumn{1}{c}{ Nama kolom } & \multicolumn{3}{c}{ Banyaknya } & $\%$ \\
nilai NULL & \\
\hline square_feet & 20.294 & 98.2 \\
space & 8.088 & 39.1 \\
description & 197 & 1 \\
bathrooms & 30 & 0.1 \\
host_has_profile_pic & 25 & 0.1 \\
bedrooms & 17 & 0.1 \\
\hline
\end{tabular}

Penghapusan data (baris) diberlakukan untuk kolom bathroom dan bedrooms yang memiliki data NULL. Hal ini dilakukan karena jumlah data yang memiliki nilai NULL kurang dari $0.1 \%$.

Penggantian isi data dilakukan untuk host_has_profile_pic. Kolom host_has profile_pic memiliki tiga jenis isi, yaitu ' $t$ ' yang berarti memiliki gambar profile, ' $\mathrm{f}$ ' yang berarti tidak memiliki gambar profile, dan 'nan' yang berarti NULL. Penulis mengganti semua data bernilai 'nan' dengan ' $\mathrm{f}$ '. Sedangkan untuk kolom description, selain karena memiliki jumlah data yang $N U L L$ hanya $1 \%$, tidak diberikan tindakan apapun dikarenakan kolom tersebut mempresentasikan deskripsi dari properti dan tidak diketahui dapat digantikan dengan nilai tertentu. Hasil akhir dari kegiatan ini didapatkan data yang memenuhi persyaratan adalah 20.623 baris dan 21 kolom.

\subsection{Exploratory Data Analysis}

Dari data yang dianalisa, terdapat 20.623 properti yang disewakan menggunakan layanan Airbnb di kota Berlin. Profil harga dari listing tersebut ditunjukkan pada Gambar 2. Gambar tersebut dibuat dengan menggunakan baris perintah sebagai berikut:

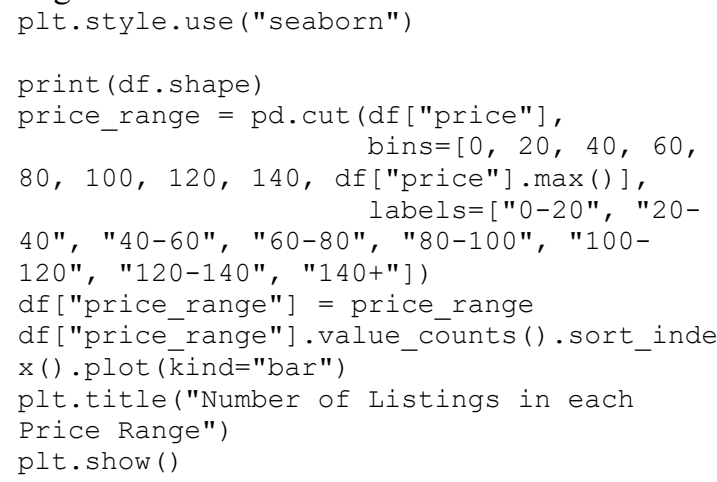

Pada gambar 2, 77\% properti disewakan dengan harga termurah $€ 20$ dan harga termahal $€ 80$. Sebanyak 39\% properti dipasarkan dengan harga sewa dikelompok harga $€ 20-€ 40$. Kelompok harga ini merupakan kelompok harga yang paling umum selain kelompok harga €40-€60. Hal yang cukup menarik adalah sekitar $4 \%$ properti dipasarkan dengan harga yang cukup mahal yaitu diatas $€ 140$ hanya berbeda $3 \%$ dengan kelompok harga terrendah. Gambar 2 menunjukkan bahwa segmentasi penyewa properti di Berlin didominasi oleh kalangan menengah.

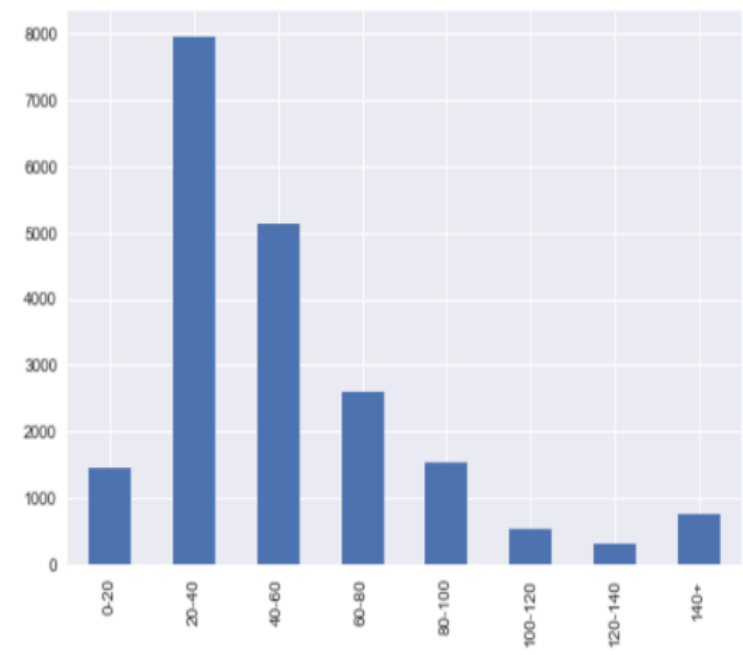

Gambar 2 Jumlah listing berdasarkan kelompok harga

Gambar 3 menunjukan sebaran lokasi properti yang disewakan. Warna pada gambar menunjukkan kelompok harga sewa dari setiap properti yang ada. Gambar tersebut dibuat dengan menggunakan baris perintah sebagai berikut:

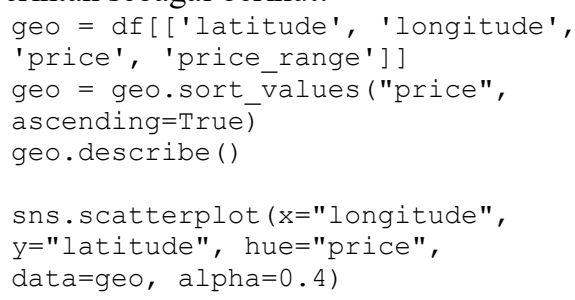

Pada gambar 3 dapat dilihat bahwa lokasi properti yang disewakan tersebar mendekati pusat kota Berlin. Bila memperhatikan profil harga sewa properti pada Gambar 2, properti yang disewakan dengan harga dibawah $€ 150$ tersebar di hampir semua kota Berlin. Mayoritas properti yang disewakan dengan harga diatas $€ 300$ berada di lokasi yang dekat dengan pusat kota Berlin.

Dari data ini dapat disimpulkan bahwa ada wisatawan yang memilih lokasi dekat ke pusat kota tetapi banyak juga wisatawan yang tidak keberatan menginap di lokasi yang tidak terlalu dekat dengan pusat kota. Hal ini mungkin dikarenakan sarana transportasi di kota Berlin sangat baik sehingga dapat mencapai pusat kota dalam waktu yang relatif singkat.

Gambar 4 menunjukan hubungan antara jarak properti ke pusat kota dengan harga sewa. Gambar tersebut dibuat dengan menggunakan baris perintah sebagai berikut:

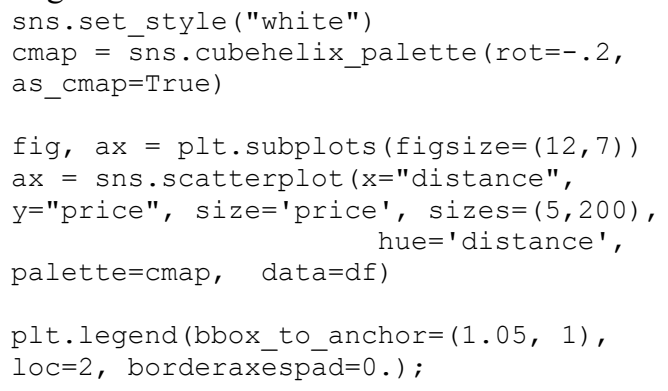




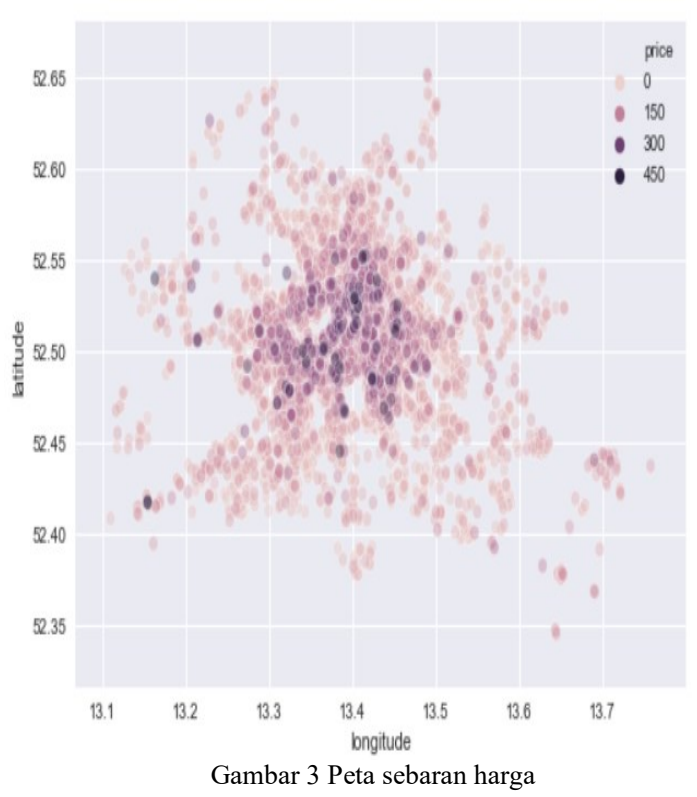

Pada gambar 4 dapat dilihat bahwa harga sewa tidak dipengaruhi oleh jarak, bahkan banyak properti dengan harga sewa mahal justru berlokasi cukup jauh dari pusat kota.

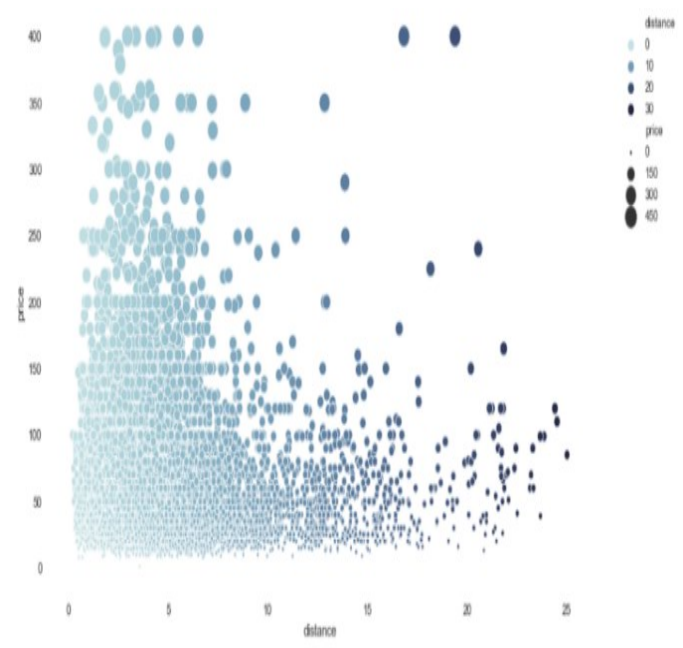

Gambar 4 Hubungan harga dengan jarak ke pusat kota

Gambar 5 merupakan visualisasi data dalam bentuk diagram boxplot. Terdapat tiga tipe kamar yaitu shared room, private room, dan entire place. Penjelasan mengenai ketiga tipe kamar tersebut adalah sebagai berikut:

- $\quad$ Shared room merupakan tipe kamar dimana para tamu tidur di kamar tidur atau area umum yang bisa berbagi dengan orang lain.

- Private room merupakan tipe kamar dimana para tamu memilik kamar pribadi untuk tidur tetapi area lain dapat berbagi dengan orang lain.

- Entire place merupakan tipe kamar dimana para tamu memiliki seluruh tempat untuk diri mereka sendiri. Tipe kamar ini termasuk kamar tidur, kamar mandi, dan dapur.
Dari gambar 5 dapat dilihat bahwa harga sewa kamar bertipe shared room merupakan yang paling murah dan yang bertipe entire place yang paling mahal. Hal ini sangat wajar karena berkaitan dengan ukuran ruangan dan tingkat privasi yang diberikan kepada para tamu. Walaupun demikian, ada beberapa pemilik properti yang menyewakan propertinya dengan harga dibawah atau diatas harga umum.

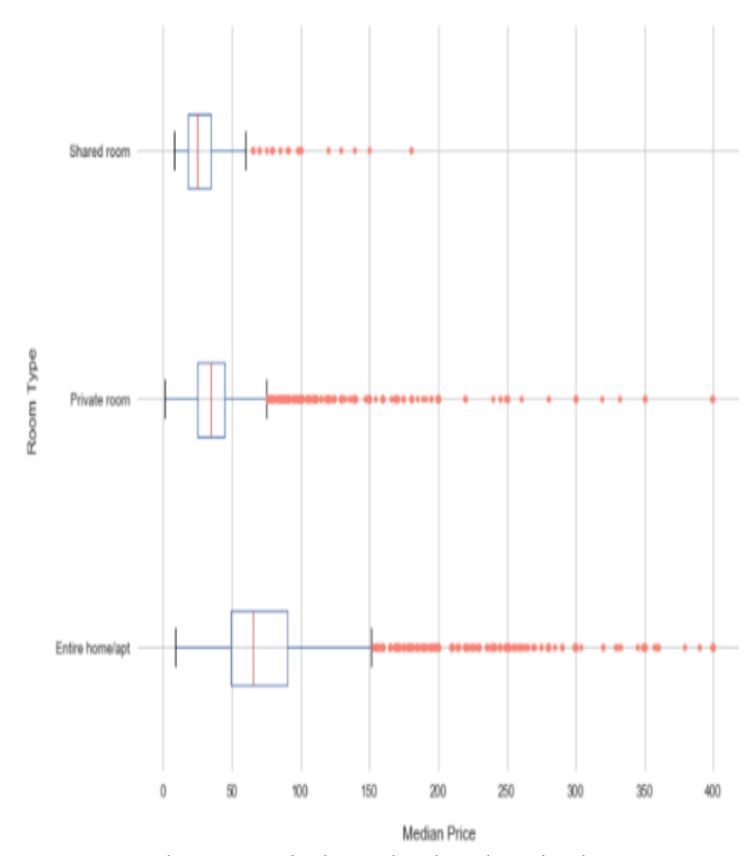

Gambar 5 Boxplot harga berdasarkan tipe kamar

Gambar 6 menunjukan jumlah properti yang dapat disewa berdasarkan jenis cancellation policy. Terdapat enam jenis cancellation policy yang disediakan oleh Airbnb, yaitu Flexible, Moderate, Strict, Long Term, Super Strict 30 Days, dan Super Strict 60 Days.

(www.airbnb.com/home/cancellation_policies).

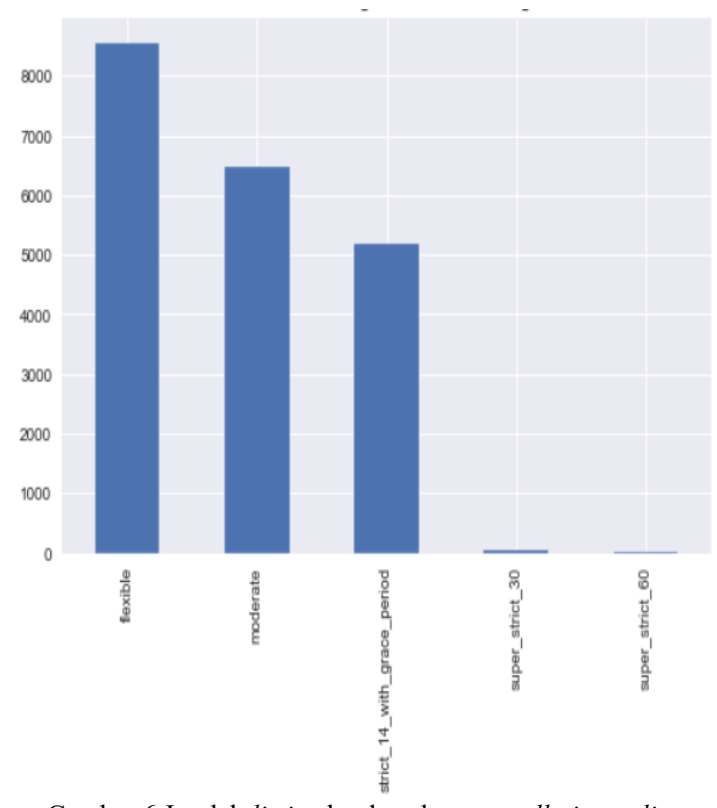

Gambar 6 Jumlah listing berdasarkan cancellation policy 
Penjelasan dari setiap policy tersebut adalah sebagai berikut:

- Flexible: Pembatalan gratis hingga 14 hari sebelum check-in (waktu ditunjukkan dalam email konfirmasi). Jika dipesan kurang dari 14 hari sebelum check-in, pembatalan gratis selama 48 jam setelah pemesanan, hingga 24 jam sebelum check-in. Setelah itu, para tamu dapat membatalkan hingga 24 jam sebelum check-in dan mendapatkan pengembalian uang dari tarif permalam dan biaya pembersihan, tetapi bukan biaya layanan.

- Moderate: Pembatalan gratis hingga 14 hari sebelum check-in (waktu ditunjukkan dalam email konfirmasi). Jika dipesan kurang dari 14 hari sebelum check-in, pembatalan gratis selama 48 jam setelah pemesanan, hingga 5 hari sebelum check-in. Setelah itu, para tamu dapat membatalkan hingga 5 hari sebelum check-in dan mendapatkan pengembalian uang dari tarif permalam dan biaya pembersihan, tetapi bukan biaya layanan.

- Strict (Strict 14 days with grace periode): Pembatalan gratis selama 48 jam, selama tamu membatalkan setidaknya 14 hari sebelum checkin (waktu ditunjukkan dalam email konfirmasi). Setelah itu, para tamu dapat membatalkan hingga 7 hari sebelum check-in dan mendapatkan pengembalian uang $50 \%$ dari tarif permalam, dan biaya pembersihan, tetapi bukan biaya layanan.

- Super Strict 30 Days: Para tamu dapat membatalkan setidaknya 30 hari sebelum checkin dan mendapatkan pengembalian uang 50\% dari tarif permalam dan biaya pembersihan, tetapi bukan biaya layanan Biaya layanan Airbnb tidak dapat dikembalikan. Kebijakan ini atas undangan hanya untuk tuan rumah tertentu dalam keadaan khusus.

Super Strict 60 Days: Para tamu dapat membatalkan setidaknya 60 hari sebelum check-in dan mendapatkan pengembalian uang 50\% dari tarif permalam dan biaya pembersihan, tetapi bukan biaya layanan. Biaya layanan Airbnb tidak dapat dikembalikan. Kebijakan ini atas undangan hanya untuk tuan rumah tertentu dalam keadaan khusus.

Dari gambar 6, dapat dilihat bahwa properti yang menerapkan cancellation policy super strict sangat sedikit bila dibandingkan dengan jenis cancellation policy lainnya. Hal ini kemungkinan besar disebabkan karena adanya unsur undangan dari pemilik properti dan hanya jenis properti tertentu saja yang disewakan dengan jenis cancellation policy tersebut.

Gambar 7 menunjukkan rata-rata harga sewa berdasarkan jenis cancellation policy. Dari gambar tersebut dapat dilihat bahwa harga sewa properti yang memiliki jenis cancellation policy super strict 60 days adalah yang paling mahal dibandingkan dengan jenis lainnya. Dari data yang ada dalam dataset, tidak diketahui penyebab mahalnya properti dengan jenis cancellation policy ini.

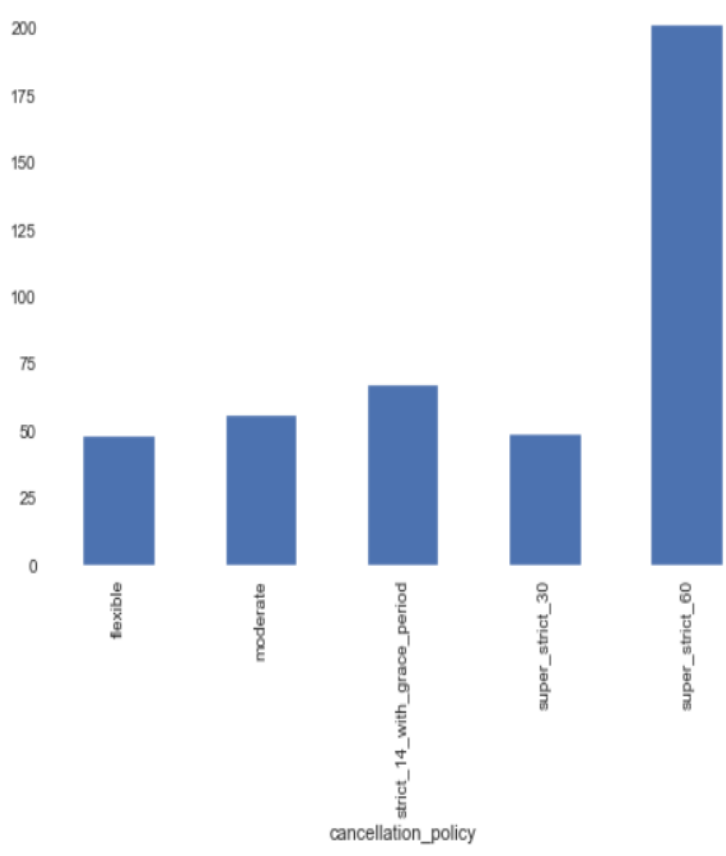

Gambar 7 Rata-rata harga berdasarkan cancellation policy

Gambar 8 menunjukan hubungan jumlah kamar tidur dengan harga sewa dikelompokkan berdasarkan district. Dari gambar tersebut terdapat properti yang tidak menyediakan kamar tidur. Hal tersebut dimungkinkan untuk properti yang bertipe shared room. Pada properti bertipe shared room, tamu dapat tidur di suatu ruangan yang ada tempat tidur atau sofa bed, tidak harus di kamar tidur. Secara umum, jumlah kamar tidur mempengaruhi harga sewa properti di semua district. Semakin banyak kamar tidur yang tersedia, harga sewa properti semakin mahal.

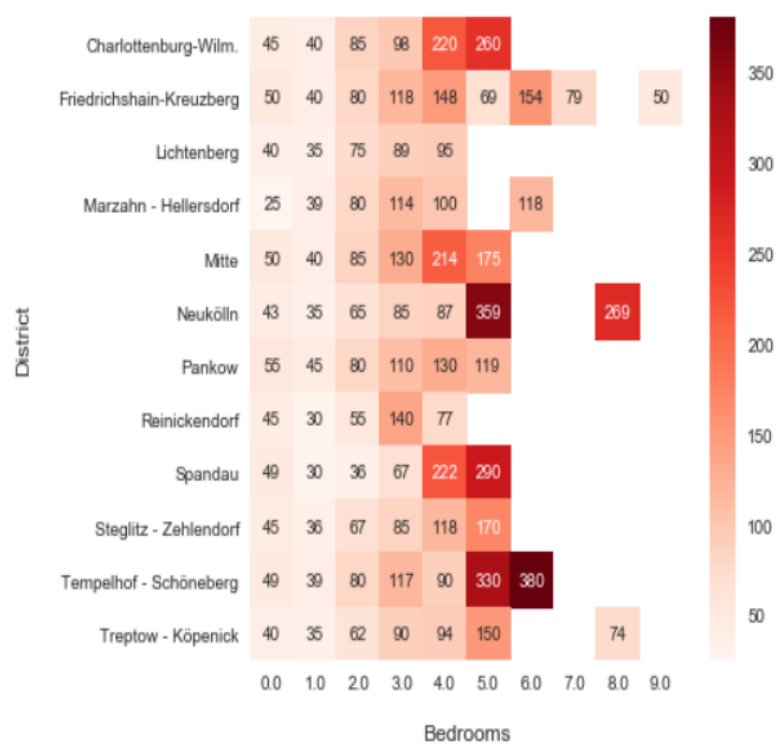

Gambar 8 Heatmap harga per distrik berdasarkan jumlah kamar tidur 


\subsection{Pemodelan}

Pada tahapan pemodelan, dataset dibagi menjadi kelompok training dan test dengan komposisi $80 \%$ data training dan $20 \%$ data test. GridSearchCV digunakan untuk mendapatkan parameter terbaik yang dapat digunakan dalam algoritma XGBoost. Baris perintah yang digunakan adalah sebagai berikut:

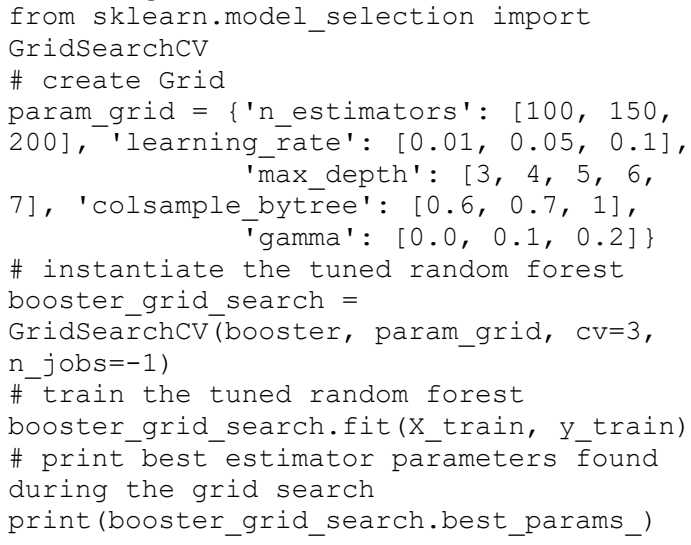

Hasil pencarian menggunakan GridSearchCV didapatkan parameter terbaik yang dapat digunakan dalam algoritma XGBoost dapat dilihat pada Tabel 5.

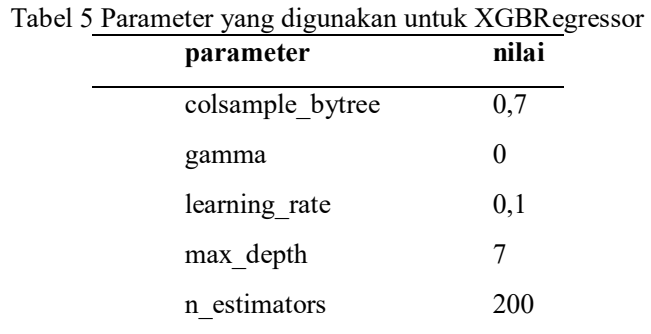

Dengan menggunakan parameter pada Tabel 5 , dijalankan baris perintah berikut:

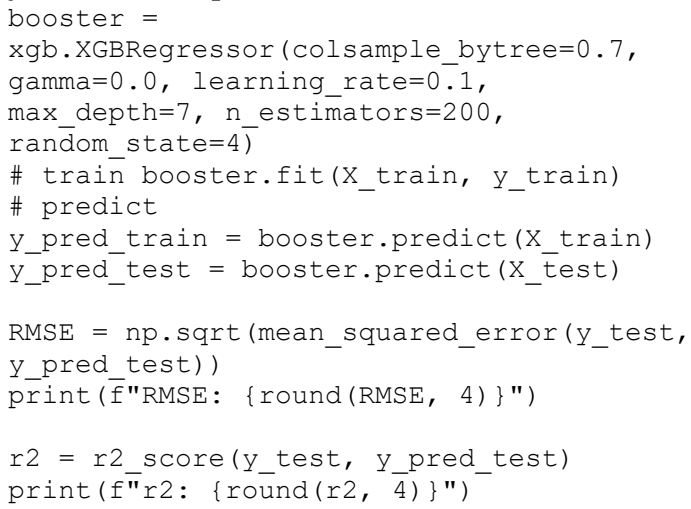

Nilai RMSE (Root Mean Square Error) yang didapatkan setelah menjalankan XGBRegressor adalah 22.588 dengan nilai $\mathrm{r} 2=0.6874$.

Cross Validation dengan menggunakan baris perintah sebagai berikut:

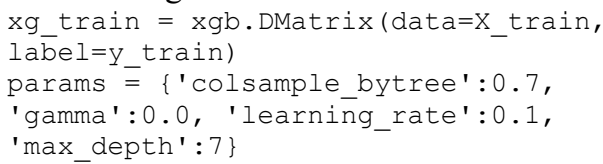

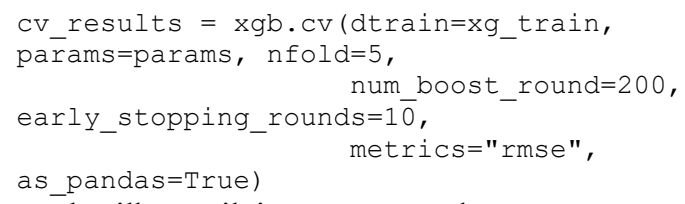

menghasilkan nilai train-rmse dan test-rmse pada head seperti yang ditunjukkan pada Tabel 6, dan nilai train-rmse dan test-rmse pada tail seperti yang ditunjukkan pada Tabel 7.

Tabel 6 Hasil cross validation pada head

\begin{tabular}{ccccc}
\hline & $\begin{array}{c}\text { train-rmse- } \\
\text { mean }\end{array}$ & $\begin{array}{c}\text { train- } \\
\text { rmse-std }\end{array}$ & $\begin{array}{c}\text { test-rmse- } \\
\text { mean }\end{array}$ & $\begin{array}{c}\text { test-rmse- } \\
\text { std }\end{array}$ \\
\hline 0 & 61.413065 & 0.267013 & 61.475652 & 1.152245 \\
1 & 56.276647 & 0.226494 & 56.481297 & 1.143789 \\
2 & 51.809781 & 0.221757 & 52.143329 & 1.115836 \\
3 & 47.822890 & 0.182698 & 48.325701 & 1.184798 \\
4 & 44.297269 & 0.109181 & 44.972254 & 1.243944 \\
\hline
\end{tabular}

\begin{tabular}{ccccc}
\multicolumn{6}{c}{ Tabel 7 Hasil cross validation pada tail } \\
\hline & $\begin{array}{c}\text { train- } \\
\text { rmse-mean }\end{array}$ & $\begin{array}{c}\text { train- } \\
\text { rmse-std }\end{array}$ & $\begin{array}{c}\text { test-rmse- } \\
\text { mean }\end{array}$ & $\begin{array}{c}\text { test-rmse- } \\
\text { std }\end{array}$ \\
\hline 195 & 11.310968 & 0.220501 & 22.081894 & 0.815590 \\
196 & 11.281500 & 0.221624 & 22.077914 & 0.816128 \\
197 & 11.262576 & 0.219708 & 22.076018 & 0.816999 \\
198 & 11.236133 & 0.216142 & 22.075180 & 0.816030 \\
199 & 11.208509 & 0.216693 & 22.072951 & 0.817962 \\
\hline
\end{tabular}

Gambar 9 menunjukkan sepuluh features importance teratas yang dihasilkan oleh algoritma XGBoost. Gambar ini dihasilkan dengan menggunakan baris perintah sebagai berikut:

feat importances $=$

pd.Sēries (booster.feature_importances_, index=features_recoded.columns)

feat importances.nlargest (10). sort values ( ).plot (kind='barh', color='darkgrey'', figsize $=(10,5))$

plt.xlabel('Relative Feature Importance with XGBoost');

Properti dengan tipe private room, entire homelapt, dan cancellation policy jenis super strict 60 days merupakan tiga fitur teratas yang direkomendasikan memiliki pengaruh signifikan terhadap penentuan harga. Luas properti dan banyaknya kamar tidur yang tersedia menempati urutan keempat dan kelima menurut data Airbnb kota Berlin.

\section{KESIMPULAN}

Pada penelitian ini telah dilakukan serangkaian tahapan penelitian menggunakan pendekatan machine learning. Kesimpulan yang didapatkan dari penelitian ini adalah sebagai berikut:

- Algoritma XGBoost yang dijalankan pada data Airbnb kota Berlin menghasilkan nilai RMSE sebesar 22.588 dan nilai $\mathrm{r} 2=0.6874$.

- Tiga fitur yang paling mempengaruhi harga sewa berdasarkan rekomendasi algoritma XGBoost adalah properti dengan tipe private room, entire place, dan cancellation policy jenis super strict 60 days.

- Feature importance yang dihasilkan oleh algoritma sangat dipengaruhi oleh keadaan data 
pada dataset. Rekomendasi fitur yang dapat memperngaruhi harga ini dapat digunakan sebagai salah satu pertimbangan dalam menentukan harga sewa bagi pemilik properti yang ingin menyewakan propertinya di Airbnb, terutama di kota Berlin.

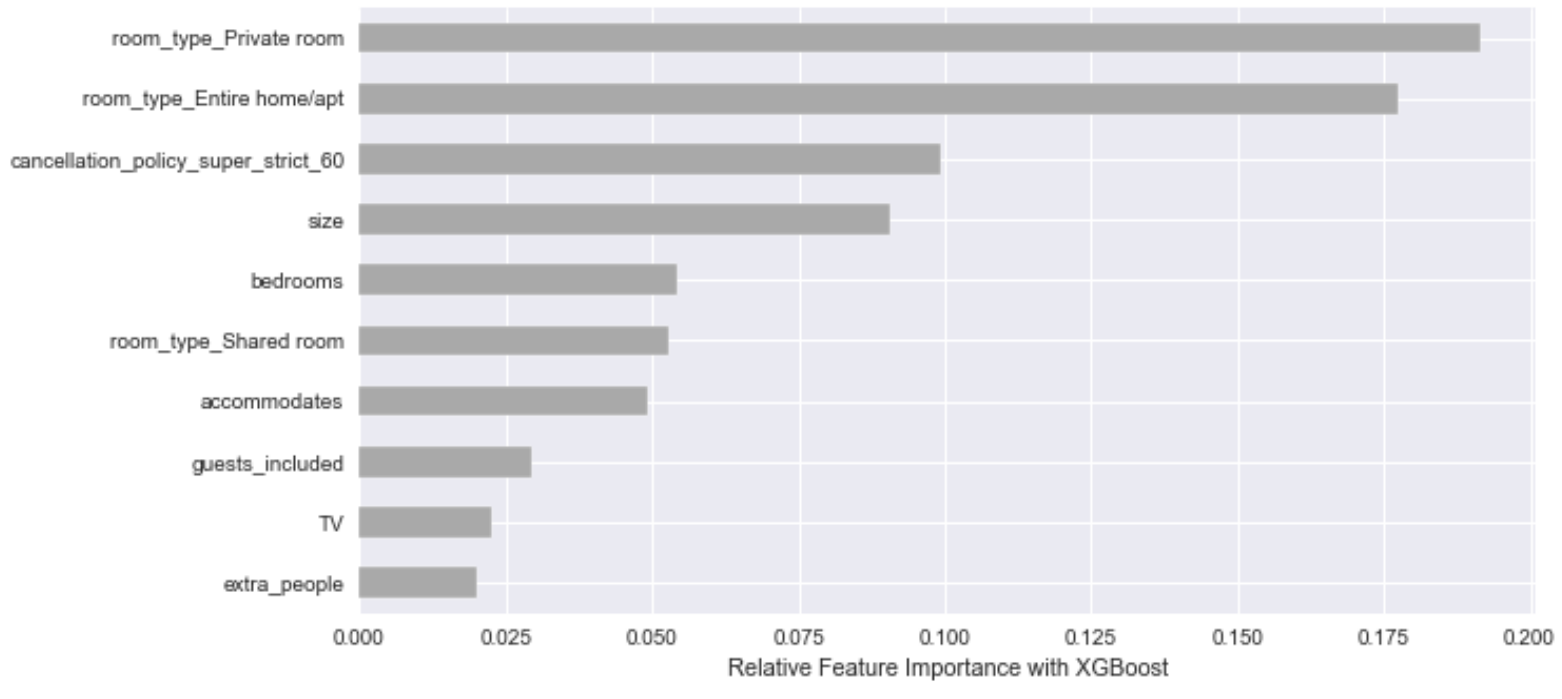

Gambar 9 Feature importance berdasarkan algoritma XGBoost

\section{DAFTAR PUSTAKA}

BATCH, ANDREA dan NIKLAS ELMQVIST. 2018. "The Interactive Visualization Gap in Initial Exploratory Data Analysis". IEEE Transactions on Visualization and Computer Graphics 24: 278-87. $<$ https://doi.org/10.1109/TVCG.2017.2743990 $>$.

BONDAREV, N. V. 2019. "Classification and Prediction of Sodium and Potassium Coronates Stability in Aqueous-Organic Media by Exploratory Data Analysis Methods". Russian Journal of General Chemistry 89: 281-91. $<$ https://doi.org/10.1134/S1070363219020191 $>$.

CAMACHO, JOSÉ, RAFAEL A. RODRÍGUEZGÓMEZ dan EDOARDO SACCENTI. 2017. "Group-Wise Principal Component Analysis for Exploratory Data Analysis". Journal of Computational and Graphical Statistics 26: 501-12.

$<$ https://doi.org/10.1080/10618600.2016.1265 $527>$.

FARISHA ISA, NINA, NOR ADILA ROSLI, FAIRUZ HAKIM dan IRINA MOHD AKHIR. 2017. "Impact of Web and Digital Experience on the Stickiness of Third Party Hotel Website". Malaysia Journal of Tourism. Vol. 9.

GARCÍA, SALVADOR, JULIÁN LUENGO dan FRANCISCO HERRERA. 2016. "Tutorial on Practical Tips of the Most Influential Data Preprocessing Algorithms in Data Mining". Knowledge-Based Systems 98: 1-29. $<$ https://doi.org/10.1016/j.knosys.2015.12.006 $>$.

GUTTENTAG, DANIEL, STEPHEN SMITH,
LUKE POTWARKA dan MARK HAVITZ. 2018. "Why Tourists Choose Airbnb: A Motivation-Based Segmentation Study". Journal of Travel Research 57: 342-59. $<$ https://doi.org/10.1177/0047287517696980> [accessed 19 February 2020].

JEBB, ANDREW T., SCOTT PARRIGON dan SANG EUN WOO. 2017. "Exploratory Data Analysis as a Foundation of Inductive Research". Human Resource Management Review 27: 265-76. $<$ https://doi.org/10.1016/j.hrmr.2016.08.003>.

LI, LING dan K. W. CHAU. 2017. "Measuring Price Differentials Between Large and Small Housing Units: The Case of Hong Kong”. In: . Proceedings of the 20th International Symposium on Advancement of Construction Management and Real Estate. Springer Singapore. 663-75. $<$ https://doi.org/10.1007/978-981-10-08559 58>.

MOREN̄O-IZQUIERDO, L., A. RUBIASERRANO, J. F. PERLES-RIBES, A. B. RAMÓN-RODRÍGUEZ dan M. J. SUCHDEVESA. 2020. "Determining Factors in the Choice of Prices of Tourist Rental Accommodation. New Evidence Using the Quantile Regression Approach". Tourism Management Perspectives 33: 100632. $<$ https://doi.org/10.1016/j.tmp.2019.100632>.

NUZZO, REGINA L. 2019. "Histograms: A Useful Data Analysis Visualization". $P M$ and $R$. $<$ https://doi.org/10.1002/pmrj.12145>.

OSHODI, OLALEKAN SHAMSIDEEN, WELLINGTON DIDIBHUKU THWALA, TAWAKALITU BISOLA ODUBIYI, ROTIMI BOLUWATIFE ABIDOYE dan 
CLINTON OHIS AIGBAVBOA. 2019. "Using Neural Network Model to Estimate the Rental Price of Residential Properties". Journal of Financial Management of Property and Construction 24: 217-30. $<$ https://doi.org/10.1108/JFMPC-06-20190047>.

OSKAM, JEROEN dan ALBERT BOSWIJK. 2016. "Airbnb: The Future of Networked Hospitality Businesses". Journal of Tourism Futures 2: 2242. $<$ https://doi.org/10.1108/JTF-11-2015$0048>$.

PHAN, THE DANH. 2019. "Housing Price Prediction Using Machine Learning Algorithms: The Case of Melbourne City, Australia". In: . Proceedings - International Conference on Machine Learning and Data Engineering, ICMLDE 2018. Institute of Electrical and Electronics Engineers Inc. 8-13. $<$ https://doi.org/10.1109/iCMLDE.2018.00017 $>$.

RAMÍREZ-GALLEGO, SERGIO, BARTOSZ KRAWCZYK, SALVADOR GARCÍA, MICHAE WOŹNIAK dan FRANCISCO HERRERA. 2017. "A Survey on Data Preprocessing for Data Stream Mining: Current Status and Future Directions". Neurocomputing 239: $39-57$. $<$ https://doi.org/10.1016/j.neucom.2017.01.07 $8>$.

SHAHHOSSEINI, MOHSEN, GUIPING HU dan HIEU PHAM. 2020. "Optimizing Ensemble Weights for Machine Learning Models: A Case Study for Housing Price Prediction". In: . INFORMS International Conference on Service Science. Springer, Cham. 87-97. $<$ https://doi.org/10.1007/978-3-030-309671_9> [accessed 19 February 2020].

VARMA, AYUSH, ABHIJIT SARMA, SAGAR DOSHI dan ROHINI NAIR. 2018. "House Price Prediction Using Machine Learning and Neural Networks". In: . Proceedings of the International Conference on Inventive Communication and Computational Technologies, ICICCT 2018. Institute of Electrical and Electronics Engineers Inc. 193639.

$<$ https://doi.org/10.1109/ICICCT.2018.847323 $1>$.

WANG, DAN dan JUAN L. NICOLAU. 2017. "Price Determinants of Sharing Economy Based Accommodation Rental: A Study of Listings from 33 Cities on Airbnb.Com". International Journal of Hospitality Management 62: 12031.

$<$ https://doi.org/10.1016/j.ijhm.2016.12.007>.

YANG, LINCHUAN, BO WANG, JIANGPING ZHOU dan XU WANG. 2018. "Walking Accessibility and Property Prices".
Transportation Research Part D: Transport and Environment 62: 551-62. $<$ https://doi.org/10.1016/j.trd.2018.04.001>.

YANG, LINCHUAN, JIANGPING ZHOU, OLIVER F. SHYR dan (DEREK) DA HUO. 2019. "Does Bus Accessibility Affect Property Prices?" Cities 84: 56-65. $<$ https://doi.org/10.1016/j.cities.2018.07.005>.

ZGRAGGEN, EMANUEL, ALEX GALAKATOS, ANDREW CROTTY, JEAN DANIEL FEKETE dan TIM KRASKA. 2017. "How Progressive Visualizations Affect Exploratory Analysis". IEEE Transactions on Visualization and Computer Graphics 23: 1977-87. $<$ https://doi.org/10.1109/TVCG.2016.2607714 $>$. 
Halaman ini sengaja dikosongkan 